\title{
Pengabdian Kepada Masyarakat Uji Kompetensi Siswa-siswi Bidang Keahlian Teknik Kendaraan Ringan di SMK Rigomasi Bontang
}

\author{
Ratnawati \\ Program Studi Teknik Mesin Sekolah Tinggi Teknologi Industri Bontang, Indonesia \\ Jl. Brigjen Katomso No 40 Bontang - Indonesia 75311 \\ *azahabr@gmail.com
}

\begin{abstract}
The Expertise Competency Test (UKK) aims to measure the achievement of student competence at a certain level according to the competence of skills taken during the learning period in SMK. UKK is implemented by education units in the form of practical exams that test aspects of knowledge, skills, and attitudes. UKK is implemented using standards set by industry, Professional Certification Institutions, and/or test kits issued by the Ministry of Education and Culture. The education unit that organizes UKK must be declared eligible as a place for professional competence testing. As in the previous year, UKK scores will be calculated as school exam scores for vocational competency subjects. The UKK toolkit issued by the Ministry of Education and Culture is open and test takers can practice using the exam tool before the exam. In general, the Expertise Competency Test consists of: (1) Vocational Practice Questions (SPK) in the form of assignments for test participants to create or process and work on a product/service; (2) Practice Question Assessment Guidelines (PPSP) are instruments used to score each assessment component, competency achievement, and assessment criteria/rubric, assessment subcomponent, competency achievement, and assessment criteria/rubric; and (3) the Verification Instrument for the Operator of the Vocational Practice Exam (InV) is an instrument used to assess the feasibility of an educational unit or other institution as a place to administer the Vocational Practice exam. Verification Instrument contains standard requirements for main equipment, standard supporting requirements, standard requirements for place or room and contains standard requirements for testers consisting of External examiners
\end{abstract}

Keywords: . Competencies, Students

\begin{abstract}
Abstrak
Uji Kompotensi Keahlian (UKK) bertujuan untuk mengukur pencapaian kompotensi siswa-siswi pada level tertentu sesuai kompotensi keahlian yang ditempuh selama masa pembelajran di SMK. UKK dilaksanakan oleh satuan pendidikan dalam bentuk ujian praktik yang menguji aspek pengetahuan,keterampilan,dan sikap.UKK dilaksanakan menggunakan standar yang ditetapkan oleh industri,Lembaga Sertifikasi Profesi,dan/atau perangkat uji yang dikeluarkan oleh Kementrian Pendidikan dan Kebudayaan. Satuan pendidikan yang menyelenggarakan UKK harus dinyatakan layak sebagai tempat uji kompotensi Profesi.Sebagaimana tahun sebelumnya ,Nilai UKK akan diperhitungkan sebagai nilai Ujian Sekolah untuk mata peljaran kompotensi kejuruan. Perangkat UKK yang dikeluarkan oleh Kemnetrian Pendidikan dan Kebudayaan bersifat terbuka dan peserta uji dapat berlatih menggunakan perangkat ujian tersebut sebelum pelaksanaan ujian . Secara umum perangkat Uji Kompotensi Keahlian terdiri atas : (1) Soal Praktik Kejuruan (SPK) adalah berupa penugasan bagi peserta uji untuk membuat atau proses dan mengerjakan suatu produk/jasa; (2) Pedoman Penilaian Soal Praktik (PPSP) adalah instrumen yang digunakan untuk pemberian skor setiap komponen penilaian,pencapaian kompotensi, dan kriteria/rubrik penilaian,sub komponen penilaian,pencapaian kompotensi, dan kriteria/rubrik penilaian; dan (3) Instrumen Verifikasi Penyelenggara Ujian Praktik Kejuruan (InV) adalah instrumen yang digunakan untuk menilai kelayakan satuan pendidikan atau institusi lain sebagai tempat penyelenggaraan ujian Praktik Kejuruan . Instrumen Verifikasi memuat standar persyaratan peralatan utama, standar persyaratan pendukung, standar persyaratn tempat atau ruangan serta memuat standar persyaratan penguji yang terdiri atas penguji External.

Kata kunci: Kompotensi, Siswa-siswi Teknik Kendaraan Ringan
\end{abstract}

\section{PENDAHULUAN}

Tridharma Perguruan Tinggi adalah Pendidikan, Penelitian, dan Pengabdian Masyarakat. Salah satu kewajiban tersebut melaksanakan Pengabdian Masyarakat, hal ini dilaksanakan berkaitan dengan kepedulian setiap lembaga atau institusi yang bergerak 
dibidang Pendidikan [Yani ddk, 2020]. Uji Kompotensi Keahlian (UKK) merupakan bagian dari intervensi Pemerintah dalam menjamin mutu pendidikan pada satuan pendidikan Sekolah Menengah Kejuruan. Pelaksanaan UKK bertujuan untuk mengukur pencapaian kompotensi siswa-siswi pada level tertentu sesuai Kompotensi Keahlian yang ditempuh selama masa pembelajaran di SMK.UKK dilaksanakan oleh satuan pendidikan dalam bentuk ujian praktik yang menguji aspek pengetahuan,keterampilandan sikap. [Yani ddk, 2020]

UKK dapat dilaksanakan menggunakan standar yang ditetapkan oleh industri,Lembaga Sertifikasi Profesi, dan/atau perangkat uji yang dikeluarkan oleh Kemntrian Pendidikan dan Kebudayaan di tempat-tempat uji kompotensi.Satuan pendidikan menyelenggarakan UKK harus dinyatakan layak sebagai tempat uji kompotensi oleh koordinator Ujian Nasional Tingkat Provinsi atau Lembaga Sertifikasi Profesi.Sebagaimana tahun sebelumnya,nilai UKK akan diperhitungkan sebagai Nilai Ujian Sekolah untuk mata pelajaran kompotensi kejuruan.

Berdasarkan Permendikbud Nomor 34 Tahun 2018 tentang Standar Nasional Pendidikan SMK/MAK,tujuan penilaian hasil belajar adalah untuk (1) mengetahui tingkat capaian hasil belajar/kompotensi peserta didik; (2) Mengetahui pertumbuhan dan perkembangan peserta didik;(3) Mengdiagnosis kesulitan belajar peserta didik; (4) mengetahui efektivitas proses pembeajaran ; dan (5) Mengetahui pencapaian kurikulum. Namun pada kenyataanyamasih banyak sekolah yang belum memahami esensi penilaian dan memenuhi tujuan penilaian seperti standar yang telah ditetapkan. Uji Kompotensi Keahlian (UKK) merupakan penilaian yang diselenggarakan khusus bagi siswa-siswi SMK untuk mengukur pencapaian kompotensi peserta didik yang setara dengan kualifikasi jenjang 2 (dua) atau 3 (tiga) pada KKNI .UKK dilaksanakn di akhir masa studi oleh Lembaga Sertifikasi Profesi atau satuan pendidikan terakriditasi bersama mitra dunia usaha/industri.Hasil UKK bagi peserta didik akan menjadi indikator ketercapaian standar kompotensi lulusan. Sedangkan bagi stakholder hasil UKK dijadikan sumber informasi atas kompotensi yang dimiliki calon tenaga kerja.

Materi UKK disuusn berdasarkan skema sertifikasi sesuai dengan jenjang kualifikasi peserta uji/asesi yang memuat kemampuan melaksanakan pekerjaan spesifik,operasional dan/atau penjaminan mutu. Soal UKK dapat berbentuk penugasan atau bentuk lain yang dinilai secara individual untuk membuat suatu produk sesuai tuntutan standar kompotensi. Dalam Pelaksanaan UKK,SMK dapat memilih salah satu atau beberapa dari 6 (enam) jenis skema penyelenggaraan ujian berikut:

1. Ujian melalui sistem sertifikasi mitra DUDIKA atau Asosiasi Profesi: SMK terakriditasi dan mitra DUDIKA atau asosiasi profesi melakukan uji kompotensi pada TUK yang telah disepakati bersama mengacu standar kualifikasi kompoensi yang ditetapkan mitra DUDI atau asosiasi profesi,asosiasi industri,atau mitra dari mitra DUDI;

2. Ujian melalui LPS Pihak Kesatu (LPS-PI): LPS yang didiirikan oleh lembaga pendiidkan ada atau pelatihan dengan tujuan utama melaksanakn sertifikasi kompotensi kerja terhadap peserta penddidikan/pelatihan berbasis kompotensi dan / atau sumber daya manusia dari jenjang kerja lembaga induknya, sesuai ruang lingkup yang dibeikan oleh BNSP;

3. Ujian melalui LPS Pihak Kedua (LPS-P2):LPS yang didirikan oleh industri atau instansi dengan tujuan utama melaksankan sertifikasi kompotensi kerja terhadap sumber daya manusia dari jenjang kernjanya,sesuai ruang lingkup yang diberikan oleh BNSP:

4. Ujian melalui LPS Pihak Ketiga (LPS-P3):LPS yang didirikan oleh asosiasi industri dan/atau asosiasi profesi dengan tujuan melkasanakan sertifikasi komoitensi kerja untuk sektor dan atau profesi tertentu sesuai ruang lingkup yang diberikan oleh BNSP:

5. Ujian melalui Panitia Teknis Uji Kompotensi (PTUK) sesuai regulasi yang dikeluarkan oleh BNSP; 
6. UKK Mandiri : SMK terakreditasi yang melakukan uji kompotensi secara mandiri menggunakan instrumen UKK yang disusun oleh pemerintah pusat sebagai standar minimal dengan melibatkan institusi pasangan dan beriontasi pada standar kompotensi lulusan.

Tujuan Pendapingan uji kompotensi keahlian Teknik Kendaraan Ringan adalah :

1. Untuk mengetahui pencapaian pengetahuan dan keterampilan siswa-siswi /siswi SMK Rigomasi Bontang di bidang Teknik Kendaraan Ringan

2. Mempersiapkan siswa-siswi /siswi SMK Rigomasi Bontang dalam memasuki dunia kerja sesuai dengan bidang keahlian Teknik Kendaraan Ringan

Sasaran uji kompotensi bidang keahlian Teknik Kendaraan Ringan adalah peningkatan pengetahuan dan keahlian siswa-siswi /siswi di bidang Teknik Kendaraan Ringan dalam memasuki dunia kerja. Adapun manfaat penyelenggaraan kegiatan uji kompotensi bidang keahlian Teknik Kendaraan Ringan adalah:

1. Sebagai alat evaluasi atas tingkat pengetahuan dan keterampilan siswa-siswi /siswi SMK Rigomasi Bontang dalam bidang keahlian Teknik Kendaraan Ringan.

2. Sebagai dasar untuk mempersiapkan siswa-siswi /siswi SMK Rigomasi di bidang keahlian Teknik Kendaraan Ringan dalam memasuki dunia kerja.

Kompotensi berasal dari kata competency yang berarti kemampuan atau kecakapan.Menurut kamus besar Bahasa Indonesia,kompotensi dapat diartikan (kewenangan) kekuasaan untuk menentukan atau memutuskan suatu hal (Dewi,Suharsono dan Haris,2014). Apabila dikaitkan dengan bidang pekrjaan, pengertian kompotensi menurut undang-undang nomor 13 tahun 2003 tentang Ketenagakerjaan adalah kemampuan kerja setiap individu yang mencakup aspek pengetahuan,keterampilan,dan sikap kerja yang sesuai dengan standar yang ditetapkan.

Berdasarkan pengertian diatas,kompotensi berkaitan erat dengan 4 (empat) hal, yakni :

a. Pengatahuan,yakni bahwa seseorang yang kompoten harus memiliki pengetahuan pada bidang yang sesuai dengan aktifitasnya. Pengetahuan dapat diperoleh dari pendidikan (formal dan non informal) serta pengalaman dalam menjalankan aktifitas yang dilakukan:

b. Keterampilan, yakni bahwa seseorang yang kompoten memiliki keterampilan dalam melaksanakan aktifivitas yang dilakukan. Keterampilan dapat diperoleh dari pelatihan serta pengalaman dalam melakukan aktifitas yang dijalankan

c. Sikap kerja,yakni keyakinan-keyakinan yang mengandung aspek kognitif,behavior, dan afektif yang merupakan kesiapan mental psikologi untuk mereaksi dan bertindak secara positif atau negatif terhadap suatu objek. Berkaitan dengan pencapaian kinerja,sikap kerja berkaitan dengan : (1) sikap terhadap organisasi; (2) sikap terhadap pekerjaan; dan (sikap terhadap rekan kerja .

\section{METODE PELAKSANAAN}

\section{Keterkaitan}

Kegiatan pengabdian pada masyarakat ini merupakan kelengkapan proses ujian SMK Rigomasi Bontang dimana dalam uji kompotensi harus menghadirkan pendamping yang berasal dari perguruan tinggi dan indutri. Teknis pelaksanaan uji kompotensi dikoordinir oleh Lembaga Penelitian dan pengabdian Masyarakat (LPPM) dengan dukungan sumber daya manusia yang memiliki latar belakang keilmuan dibidang Teknik Kendaraan Ringan . Hal ini yang berkaitan dengan sumber daya manusia LPPM STTI Bontang dapat dijelaskana sebagai berikut:

a. Tenaga Pengajar yang profesional dan berpengalaman 
b. Tenaga pengajar yang profesional dan berpengalaman dalam pelaksanaan kegiatan pendidikan dan pelatihan.

\section{Metode Kegiatan}

Kegiatan ini berupa pendampingan dalam pelaksanaan uji kompotesni bidang keahlian Teknik Kendaraan Ringan. Berikut disajikan tahapan uji kompotensi yang dilakukan:

1. Tahapan Persiapan

Pada tahap persiapan hal yang dilakukan meliputi :
a. Pemaparan rencana uji kompotensi bidang keahlian Teknik Kendaraan Ringan oleh Kepala SMK Rigomasi Bontang
b. Pembagian bidang keahlian berdasarkan kompotensi penguji eksternal
c. Penentuan jadwal kegiatan uji kompotensi

2. Tahap pelaksanaan Ujian

a. Memelihara/Servis Unit Kopling dan Komponen -Komponennya Sistem Pengoperasian

b. Memelihara/servis transmisi manual

c. Memelihara/Servis Unit Final Drive / Gardan

d. Perakitan dan pemasangan sistem rem dan komponen-komponennya

e. Pemeliharan /servis sistem rem

f. Perbaikan Sistem Rem

g. Overhaul sistem Rem

h. Memelihara/Servis Sistem Kemudi

i. Memelihara/Servis Sistem Suspensi

j. Perbaikan Ringan pada Rangkalan / Sistem Kellstrikan

k. Memperbaiki sistem starter dan pengisian

1. Memasang, Menguji dan Memperbaiki Sistem Penerangan dan Wiring

m. Memasang, Menguji dan Memperbaiki Sistem Pengaman Kelistrikan dan Komponennya

n. Memperbaiki Sistem Pengapian

o. Memasang Sistem A/C (Air Conditioner)

p. Memperbaiki/Retrofit Sistem A/C (Air Conditioner)

q. Memelihara/Servis Sistem A/C (Air Conditioner)

3 Metode Kegiatan

Metode kegiatan uji kompotensi bidang keahlian Teknik Kendaraan Ringan di SMK Rigomasi Bontang dilakukan berupa pendampingan pada waktu pelaksanaan ujian kompotensi berlangsung. Pendampingan dimaksud berupa penguji yang berasal dari pihak eksternal SMK Rigomasi Bontang

\section{HASIL DAN PEMBAHASAN}

\section{Hasil}

Kegiatan uji kompotensi bidang keahlian Teknik Kendaraan Ringan bagi siswa-siswi SMK Rigomasi Bontang, Waktu penyelenggaraan dilaksanakan pada tanggal 5-7 April 2021. Kegiatan uji kompotesni bidang keahlian Teknik Kendaraan Ringan pada waktu pelaksanaan ujian kompotensi berlangsung.Pendamping merupakan komponen penguji yang berasal dari pihak eksternal SMK Rigomasi Bontang.

Evaluasi uji kompotensi bidang keahlian Teknik Kendaraan Ringan di SMK Rigomasi Bontang berjalan sesuai dengan rencana yang telah ditentukan.secara umum,siswa-siswi SMK 
URL:

http://www.sttibontang.ac.id/jurnal/index.php/pay

Rigomasi Bontang dapat melaksanakan uji kompotensi bidang keahlian Teknik Kendaraan Ringan dengan melakukan pembongkaran,pemeriksaan dan pemasangan komponenkomponen unit kerja. Pemahaman siswa-siswi SMK Rigomasi di Bidang Teknik kendaraan Ringan yang diujikan sangat baik . Hal ini dibuktikan dengan proses cara kerja dan jawaban peserta yang mayoritas dapat melakukan proses pembongkaran dan pemasangan kembali komponen tiap unit dengan baik dan benar.

\section{Pembahasan}

Kegiatan program Pengabdian kepada Masyarakat (PkM) yang diselenggarakan oleh Lembaga Penelitian dan pengabdian pada masyarakat (LPPM) STTI Bontang Kesatuan ini telah terselenggara sesuai dengan rencana yang ditetapkan . Uji kompotensi bidang keahlian Teknik Kendaraan Ringan merupakan ramgakian ujian akhir yang diselenggarakan oleh SMK Rigomasi Bontang bagi siswa-siswi jurusan Teknik Kendaraan Ringan Kelas XII. Dalam pelkasanaanya, SMK Rigomasi Bontang menginstruksikan pihak eksternal yang berasal dari perguruan tinggi dan industri yang terkait dengan bidang kompotensi di SMK Rigomasi Bontang .

Harapan yang ingin di capai adalah terbentuknya link and match antara dunia pendidikan yang merupakan lembaga penyuplai tenaga kerja dengan industri sebagai pengguna tenaga kerja. Lembaga pendidikan kejuruan memiliki tanggung jawab untuk membekali pengetahuan dan keterampilan bagi siswa-siswi yang kelak akan bekerja pada industri sesuai dengan bidangnya. Dengan demikian, angkatan tenaga kerja yang diserap oleh dunia kerja akan optimal sehingga dapat menurunkan tingkat pengangguran di Indonesia.

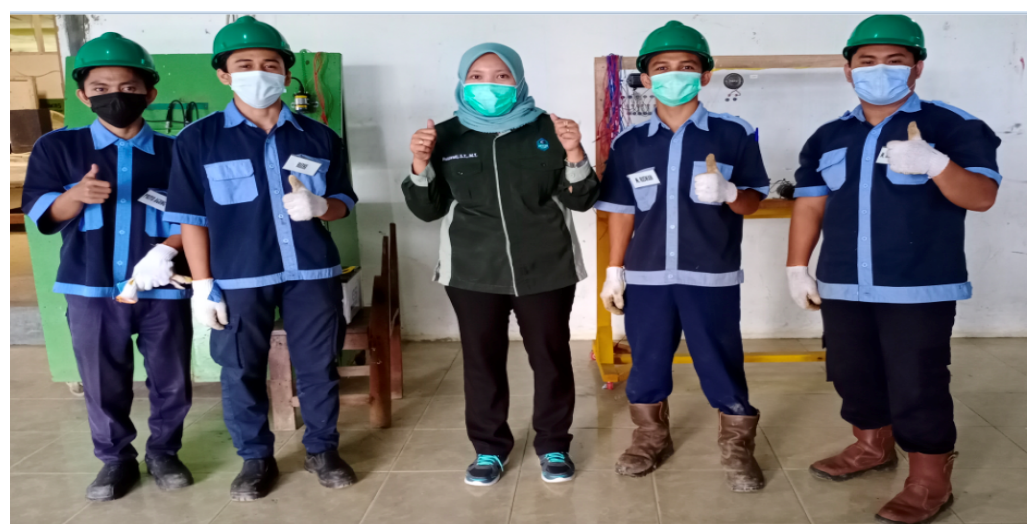

Gambar 1. Foto bersama peserta Siswa-siswi UKK

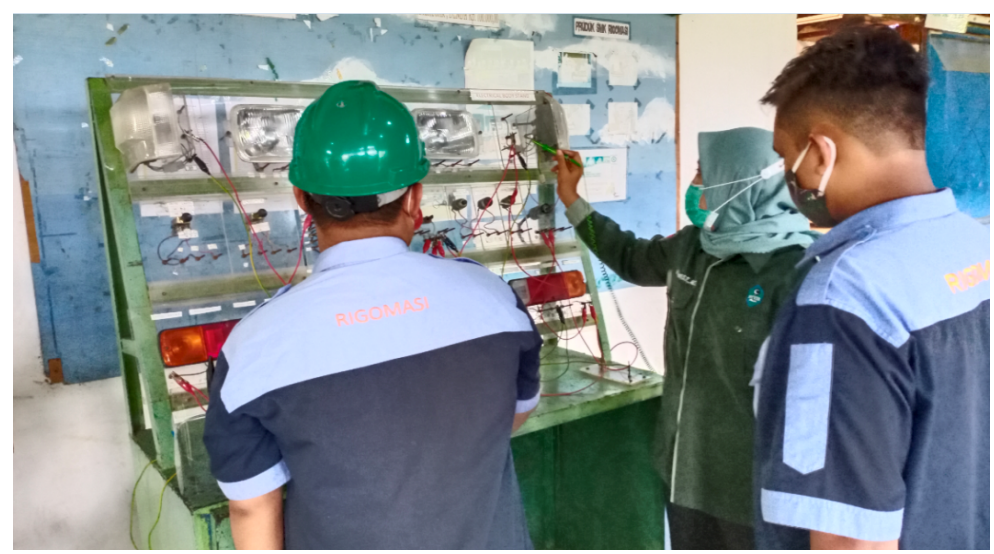

Gambar 2. Melakukan Uji Pengetesan Kelistrikan Body 
JPAY Vol. 1 No. 1. 2021

(Jurnal Pengabdian Ahmad Yani) STTI Bontang

URL:

http://www.sttibontang.ac.id/jurnal/index.php/pay

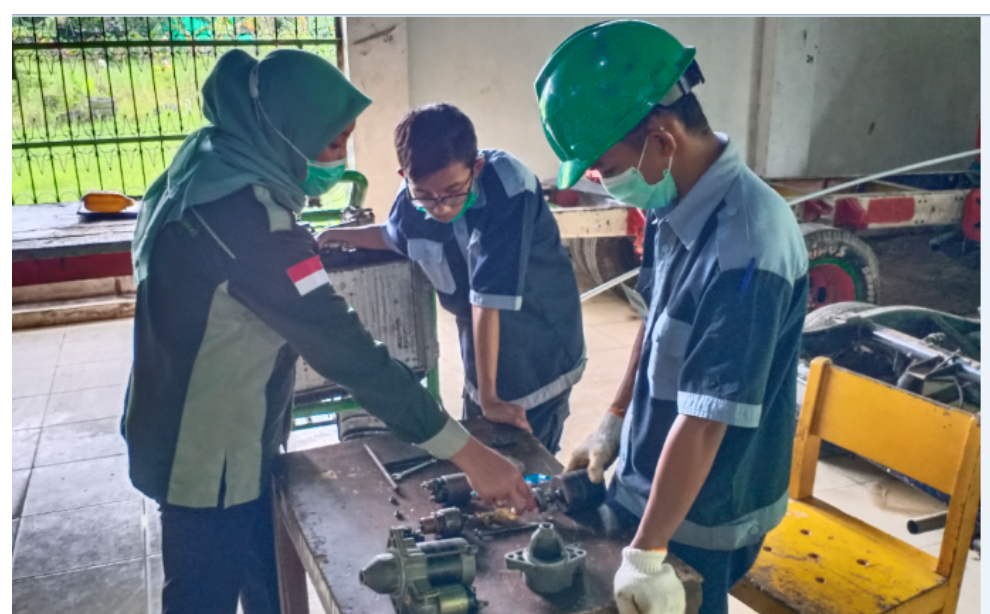

Gambar 3. Pengujian sistem Stater (Kelistikan Mesin)

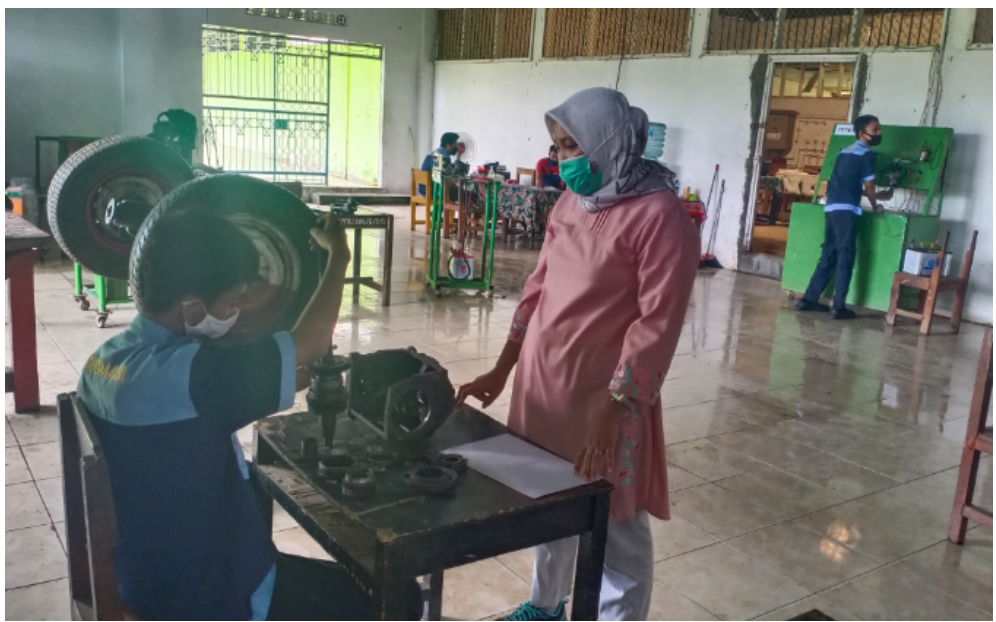

Gambar 4. Pengujian Deferensial

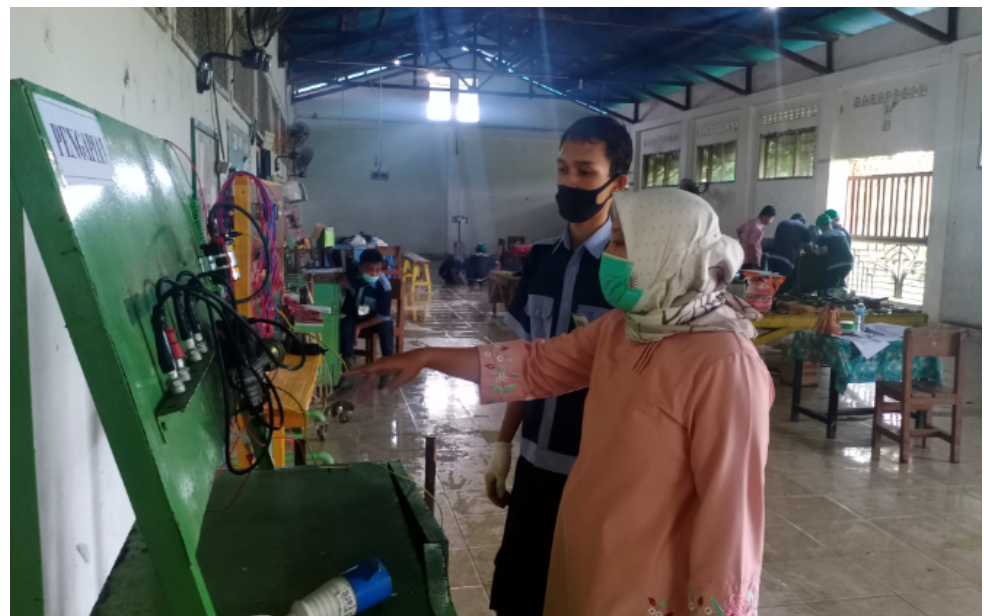

Gambar 5. Pengujian Rangkaian sistem Pengapian (Kelistikan Mesin) 


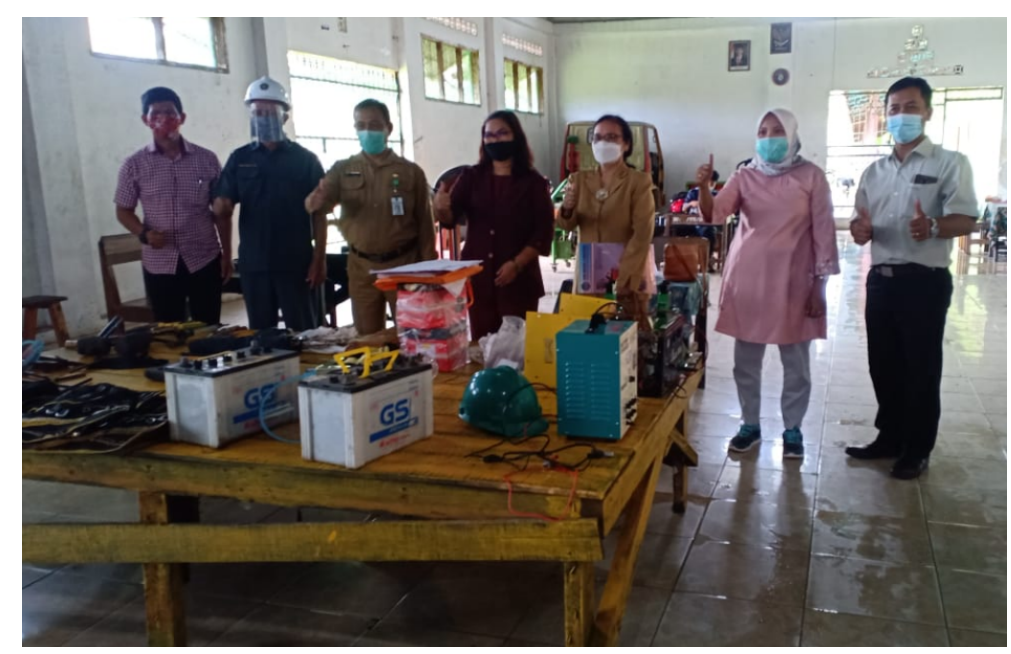

Gambar 6. Kunjungan Tim Dinas Pendidikan Kota Bontang

\section{KESIMPULAN}

Meskipun masih dalam kondisi pandemic Covid -19, teknis pelaksanann UKK tetap menerapkan protokol kesehatan. UKK ini dilaksanakan kelas XII sebagai bahan evaluasi terhadap kemampuan kompotensi keahlian dari masing-masing siswa-siswi , serta sebagai bekal akan kemampuan siswa-siswi nanti menghadapi kesiapan di dunia kerja. Antusiasme siswa-siswi SMK Rigomasi ini menjadi sebuah nilai bahwa pada masa pandemi COVID-19 ini tidak menjadikan dilema tersendiri terhadap kewajiban siswa-siswi SMK Rigomasi Bontang atas menilai kemampuan kompotensinya pada bidang masing-masing keahlian , kewajiban seorang pelajar ditaati dengan penuh tanggung jawab karna hal ini juga bagian dari sebuah semangat dalam menggapai sebuah prestasi.

Semoga apa yang telah dilaksanakan siswa-siswi, mendapatkan nilai-nilai terbaik sesuai apa yang diharapkan serta apa yang mereka cita-citakan dapat tercapai dengan kerja keras yang mereka lakukan.

\section{DAFTAR PUSTAKA}

Dewi, Luh Retiantari., Suharsono, Naswan dan Haris, Iyus Akhmad. 2014. Pengaruh Kompetensi Pedagogik dan Kompetensi Profesional terhadap Hasil Belajar Siswa-siswi Dalam Mata Pelajaran Ekonomi Kelas X SMAN 4 Singaraja. Jurnal Pendidikan Ekonomi Undiksha. Vol. 4 No. 1.

Sudradjat ,Firdaus, Amyar. 2020. Jurnal PKM Uji Kompetensi Bidang Keahlian Akuntansi di SMK Pembangunan Kota Bogor

Susilo, (2016). Pengembangan media pembelajaran trainer kelistrikan untuk meningkatkan hasil belajar siswa-siswi SMK Muhammadiyah Kutowinangun, Universitas Muhammadiyah Purwerejo. Jurusan Pendidikan Teknik Otomotif 
Undang-undang nomor 13 tahun 2003 tentang Ketenagakerjaan $\rightarrow$ Website

Yani. A., Anoi. Y.H., \& Hamdani. W., Pelatihan Peningkatan Kompetensi Pra Uji Kompetensi Kejuruan (Ukk) Jurusan Teknik Otomotif Kepada Siswa Smk Rigomasi Bontang. Jurnal Abdimas Bina Bangsa (JABB). Vol. 1 No. 1 (2020): 128-136.

Yani. A., Ratnawati,. \& Yusuf. M.M., Pelatihan Penggunaan Software Autocad Untuk Meningkatan Kompetensi Siswa-Siswi Smk Rigomasi Bontang. Pelatihan Penggunaan Software Autocad Untuk Meningkatan Kompetensi Siswa-Siswi Smk Rigomasi Bontang. BERDAYA: Jurnal Pendidikan dan Pengabdian Kepada Masyarakat Vol. 2 No. 2. 2020. 61-68.

Yani. A., Ratnawati,. \& Anoi. Y.H., Pengenalan dan Pelatihan Autocad Untuk Meningkatkan Kompetensi Siswa Smk Nusantara Mandiri Kota Bontang. Jurnal Pendidikan dan Pengabdian Masyarakat. Vol. 3 No. 2. 2020

https://smk.kemdikbud.go.id/konten/4821/uji-kompetensi-keahlian-tahun-pelajaran-0202021. diakses pada tanggal, 27 Juni 2021

https://drive.google.com/drive/folders/1ovzi5khBLNLOsoRQV-0DM6BhdlbmqhdA. diakses pada tanggal, 27 Juni 2021

\section{Profil Penulis:}

\begin{tabular}{|l|l|} 
Ratnawati, Kelahiran Maros, 05 Agustus 1988. Penulis \\
merupakan staf pengajar Sekolah Tinggi Teknologi \\
Industri Bontang dengan bidang keahlian Konstruksi \\
Mesin.. Email: azahabr@gmail.com
\end{tabular}

